\title{
Knowledge management in a virtual organization
}

\author{
ANETA LIPIŃSKA ${ }^{1}$
}

The Jagiellonian University in Kraków, Institute of Economics, Finance and Management

\begin{abstract}
This article, which also has a nature of a review, presents issues of knowledge management in virtual organizations. The aim of the study was to identify and characterize the most important issues, i.e. the nature, subject, methods, tools, problems and benefits associated with the process of knowledge management in virtual organizations. The analysis of the literature included both Polish and foreign papers published in the twenty-first century, containing the latest theories and research results as well as classic approaches. The first part of the article describes the concept of virtual organizations, while the second contains the definitions, conditions and problems of knowledge management in this type of enterprises. The study shows the important role of knowledge and information technology, their relationships and the impact on virtualization of organization.
\end{abstract}

Paper type: review article

Keywords: knowledge management, virtual organization, virtualization, enterprises, information technology

\section{Introduction}

As a result of the impact of information technologies, changes occur both within companies and in their environment. The most significant changes concern strategies, business models, organizational structures, mobility and ability to work remotely, infrastructure and issues relating to the security of information and knowledge created in the organization (Dziembała \& Kostrubała, 2010). In addition, information technologies imply the creation of new organizational forms, includ-

1 aneta.lipinska@uj.edu.pl 
ing virtual organizations and shaping multidimensional economic environment in which these organizations operate (Sroka \& Palonka, 2010).

The relationship between the development of information technologies, especially the Internet, and the functioning of virtual organizations, is multilateral, that is, the objective of the existence of technology networks, on which these organizations are based, is the transfer of knowledge while, in virtual organizations, the effectiveness of the transfer of knowledge depends on the network performance. Technology and knowledge are the two constructive components of a virtual organization (Warner \& Witzel, 2005).

The reference of modern knowledge management to virtual organizations is connected with identifying them as open learning systems using ICT to create value in intangible (virtual) environment, which in turn leads to changes in the way they implement specific management functions.

The aim of the article was to identify and characterize the most important issues related to the process of knowledge management in virtual organizations. One of the motives for analyzing this subject was progressive virtualization of traditional companies for which structured information concerning the nature, content, methods, tools, problems and benefits of knowledge management within a specific organizational form may be useful. For virtual organizations, in turn, the increase of the efficiency of the process of knowledge management can become a source of obtaining or consolidating a competitive advantage in the market. The implementation of the objective required the analysis of literature, including the newest Polish and foreign papers, of both theoretical and scientific nature.

\section{Virtual organization}

The impact of information technologies on organizations and their environment

The widespread use of information technologies is one of the factors in the development of a new economic model which is called a sharing economy (Lessing, 2008) or Wikinomy (Tapscott \& Williams, 2006). This model is based on the following principles:

- openness, i.e. the use of ideas and intellectual potential available outside the organization,

- partnership - functioning in flexible organizational structures or self-organizing into communities in order to create a product or service,

- sharing - sharing tools, knowledge, resources or information, which increases productivity and effectiveness of achievement of those objectives,

- global action - use of technologies and human capital from around the world. 
The sharing economy is the future model of the organization in network structures, characteristic of the information society, in which users are simultaneously creators, content consumers and critics. In the context of online communities, there exist both substantive and social interactions, leading to the so-called social information processing and sharing of knowledge (Lipińska, 2014). Lessing (2008) predicts that more and more companies will emerge - hybrids drawing profits from information resources and knowledge voluntarily provided by Internet users. Contemporary examples of such activities are Wikipedia or Google and portals allowing the use of collective intelligence to solve problems of enterprises, such as: Innocentive, ${ }^{2}$ MyStarbucksIdea, ${ }^{3}$ Dell IdeaStorm, ${ }^{4}$ and others.

\section{Features of a virtual organization}

Virtual organizations are often characterized as opposed to traditional organizations as part of three dimensions, i.e. space (uniform - diverse), time (synchronous - asynchronous) and mode of interaction (face to face - online). Vartiainen (2001) proposed, under this description, adding the fourth dimension, i.e. individual differences (similarities - differences) to highlight the importance of the method of performing work and characteristics of work teams. The diagram of the dimensions of characteristics of virtual and non-virtual organizations is shown in Figure 1.

According to Underwood (2007), management based on traditional planning, organizing, leading and controlling changes in a virtual organization into coordination, learning, transformation and quality control.

Skrzypek and Senkus (2014) argue that virtual organizations differ from traditional organizations in their ability to act quickly, flexibility in decision-making, better use of resources, knowledge, competence, ability to use legislative differences between countries and the ability to overcome barriers of time and geography (telework).

Sroka and Palonka (2010) attribute the following characteristics to a virtual organization:

- adaptability, flexibility, acceptance of change and uncertainty,

- increasing the use of resources, know-how and knowledge (intellectual capital),

- ability to connect with partners to differentiate the production degree,

- reduce the level of bureaucracy, activisation of personnel,

- use of information technologies to support management processes (including knowledge management) in an organization.

\footnotetext{
${ }^{2} \mathrm{http} / / /$ www.innocentive.com/ [accessed: 8.05.2015].

${ }^{3} \mathrm{http}: / /$ mystarbucksidea.force.com/ [accessed: 8.05.2015].

${ }^{4}$ http://www.ideastorm.com/ [accessed: 8.05.2015].
} 


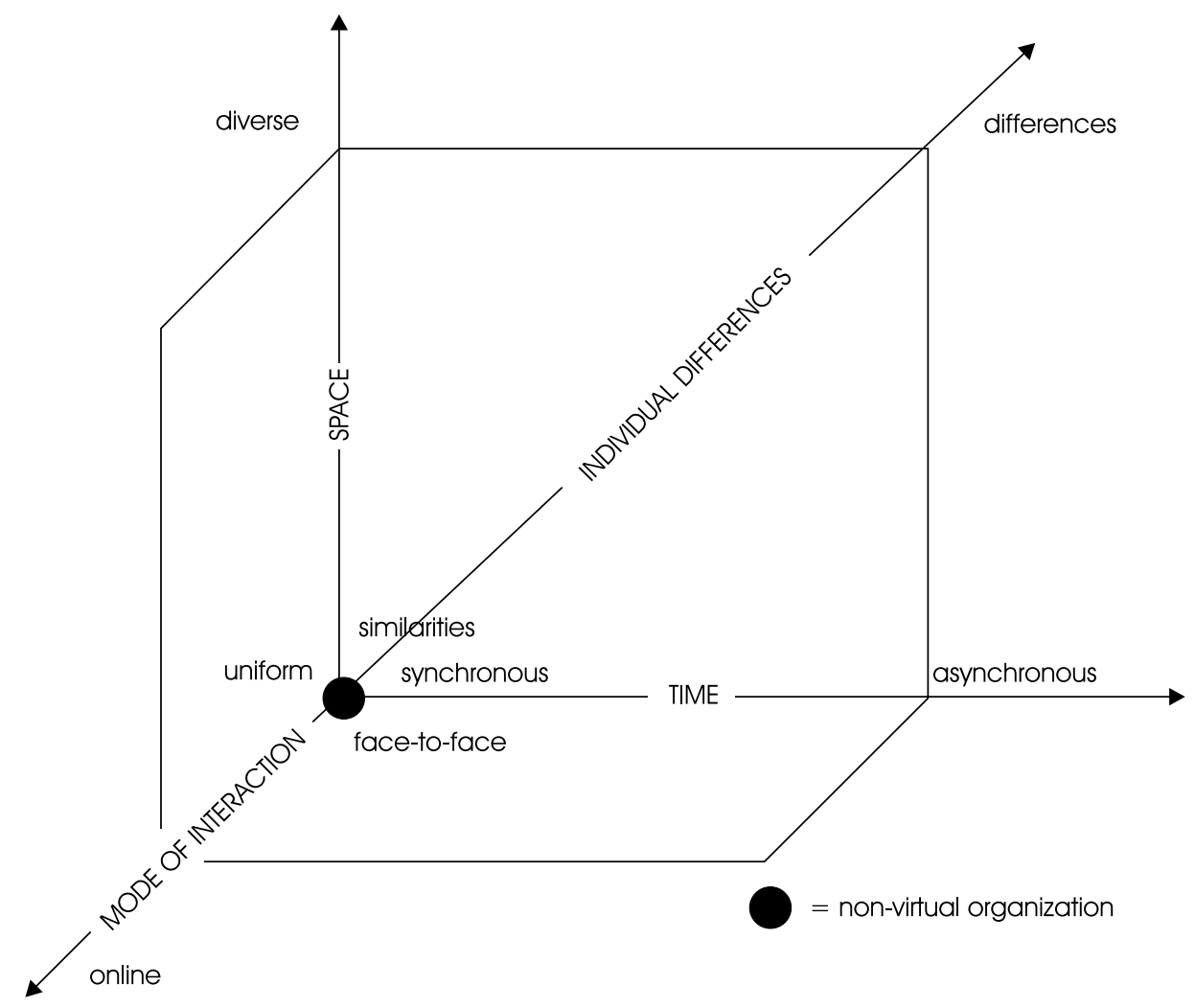

Figure 1. The dimensions of virtual and non-virtual organizations.

Source: own study based on Vartiainen (2001).

The essence of a virtual organization is also presented by Warner and Witzel (2005). According to them, virtual enterprises are characterized by:

- lack of material structure,

- basing activity on ICT,

- remote work,

- hybrid forms,

- blurring the boundaries,

- flexibility.

According to Underwood (2007), the idea of virtual organizations is a form of economic activity which is the closest to perfection, but, nevertheless, is not free of problems, arising sometimes from the same source as potential factors for its success. Selected problems and benefits in the activity of a virtual organization are presented in Table 1. 
Table 1 Selected problems and benefits in the activity of a virtual organization

\begin{tabular}{|l|l|}
\hline Benefits of the activity of a virtual organization & Problems in the activity of a virtual organization \\
\hline $\begin{array}{l}\text { Increase in productivity, reduction of fixed costs, } \\
\text { reduction of prices }\end{array}$ & $\begin{array}{l}\text { Problems associated with the management } \\
\text { process }\end{array}$ \\
\hline Development of technological potential & Technological problems \\
\hline $\begin{array}{l}\text { Overcoming geographical and time barriers in } \\
\text { work organization }\end{array}$ & $\begin{array}{l}\text { Problems with communication and meeting the } \\
\text { needs of employees (being recognized, apprecia- } \\
\text { ted, etc.), progressive dispersal of workforce }\end{array}$ \\
\hline $\begin{array}{l}\text { Ability to use and manage key resources: informa- } \\
\text { tion and knowledge }\end{array}$ & $\begin{array}{l}\text { Problems associated with information overload, } \\
\text { its selection, timeliness, usability, etc. }\end{array}$ \\
\hline $\begin{array}{l}\text { Ability to quickly anticipate changes and to react } \\
\text { flexibly to them }\end{array}$ & $\begin{array}{l}\text { No uniform (in a global scale) legal and customs } \\
\text { regulations }\end{array}$ \\
\hline Ability to focus on best practices & $\begin{array}{l}\text { Doubts about reliability and the scope of respon- } \\
\text { sibilities in virtual organizations }\end{array}$ \\
\hline
\end{tabular}

Source: Underwood (2007).

In summary, a virtual organization is based on information technologies that enable it to use resources and competences dispersed spatially, as well as share information and knowledge within the network created by the company and its stakeholders. Work in a virtual organization is performed outside the framework of time and place, taking the most common form of remote work (i.e. teleworking) as part of virtual work teams. The mode of action is determined by the purpose and benefits of cooperation undertaken, often as part of short-term projects. Virtual organizations are characterized by high flexibility and ability to respond to changes in the turbulent environment. Virtual organization management is a complex process, based to a lesser extent than in traditional enterprises on the realization of the classic functions of management and dependent on many factors, such as, globalization processes, cultural differences, bargaining power and scope of the objectives of the action.

\section{Knowledge Management}

\section{Determinants of knowledge management in organization}

Knowledge management within the meaning that can be applied not only to the traditional, but new organizational forms, such as, virtual organizations means "the management of knowledge about the company, customers, processes and using it to create additional customer value and competitive differentiation of offer and products" (Tiwana, 2003, p. 24). According to Kisielnicki and Sroka (2005), knowledge 
management is a process which uses the knowledge held in the organization, seeks and absorbs external resources and creates conditions for sharing knowledge resources by all participants in the decision-making process. According to Skrzypek (2014, p. 183), knowledge management is "a group of processes that enable the creation, dissemination and application of knowledge so that the organization can realize its qualities in an efficient manner."

In order to characterize and evaluate the importance of knowledge in the management process, it is necessary to present its place in the hierarchical structure, the so-called pyramid of knowledge. The hierarchy of the elements of the pyramid of knowledge presented in Figure 2 is a compilation of approaches represented in the Polish literature by Kisielnicki (2008) and in the world literature by Hey (2004).

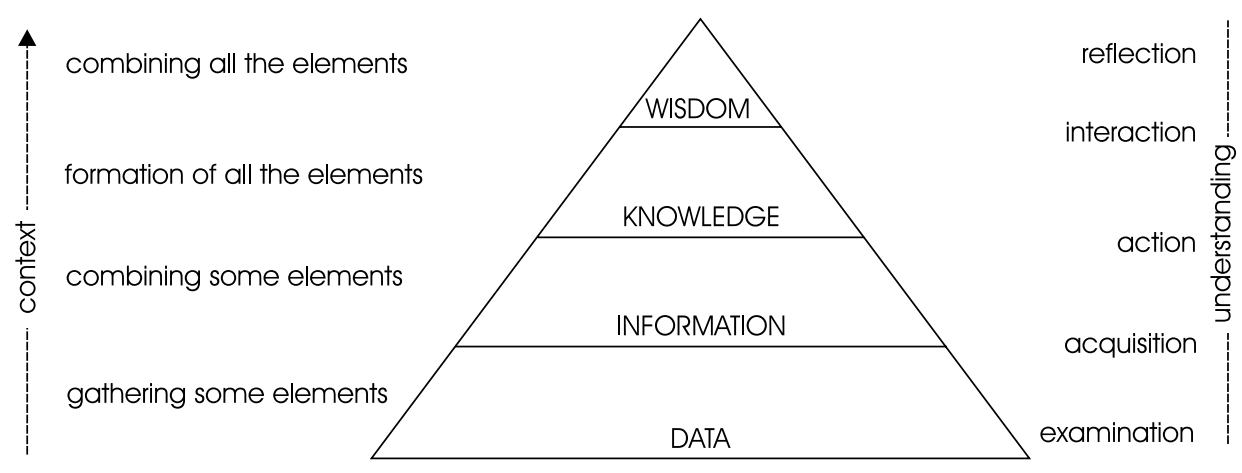

Figure 2. The hierarchy and relationships in the so-called pyramid of knowledge.

Source: own study on the basis of Hey (2004), Kisielnicki (2008).

Data, information, knowledge and wisdom, presented in a hierarchical relationship, are also called the model of intangible resources of the organization. The data are basic, the least complex and the most accessible part of the pyramid of knowledge. These are raw facts and figures about the phenomena or events. The information is the result of arrangement or analysis of data (Kisielnicki, 2008). Information in the area of management belongs to key intangible resources of an organization, is a factor increasing the knowledge of the company, reducing uncertainty in the decision-making and supporting the realization of the basic functions of management (Czekaj, 2012). Knowledge is related to the organization's resources relating to data, information, procedures as well as the experience and education of its employees and managers. In contrast to data and information, knowledge is personal, individualized and internalized (Hey, 2004). Furthermore, knowledge is associated with organizational factors, such as, culture, ethics, intuition, work- 
ing conditions and management style (Kisielnicki \& Sroka, 2005). Wisdom, rarely referred in the literature to the organization, may be treated as the ability to apply knowledge in practice, based on inference, learning from mistakes, analysing, interpreting, etc.

In the pyramid of knowledge what is also important, in addition to the hierarchical relationships of its components, are also their other mutual relations. The transformation of data into information and then into knowledge is a continuous process which creates wisdom (Hey, 2004; Kisielnicki, 2008). Its formation is affected by, among others, quality of information, experience of the subject which is the source of knowledge, cooperation, sharing of knowledge and time and technologies which increasingly and at every stage influence the processes related to the processing of information and knowledge management in the organization.

With regard to the process of knowledge management in an organization, it is important to cite the most basic and widespread division of knowledge into tacit and explicit (Nonaka \& Takeuchi, 1995; Kisielnicki \& Sroka, 2005; Davoudi $\&$ Fartash, 2012). Comparison of the characteristics of different types of knowledge within this typology is presented in Table 2.

Table 2 Tacit and explicit knowledge

\begin{tabular}{|l|l|}
\hline \multicolumn{1}{|c|}{ Explicit knowledge } & \multicolumn{1}{c|}{ Tacit knowledge } \\
\hline Formalized, codified, systematized & Difficult to formalize and codify \\
\hline Available & Ineffable and imperceptible at first \\
\hline Expressed in words and numbers & $\begin{array}{l}\text { Rooted in an individual action and experience and } \\
\text { individual and collective emotions, beliefs, values }\end{array}$ \\
\hline Easy to communicate and share & Difficult to communicate and share \\
\hline $\begin{array}{l}\text { It includes, among other things, decision } \\
\text { tables, manuals, databases, etc. }\end{array}$ & $\begin{array}{l}\text { It includes the elements of organizational culture, } \\
\text { skills of employees }\end{array}$ \\
\hline
\end{tabular}

Source: Nonaka \& Takeuchi, 1995; Kisielnicki \& Sroka, 2005; Davoudi \& Fartash, 2012.

Depending on the type of organization and the management system used in it, there occur specific relationships between it and the type of knowledge. According to Kisielnicki and Sroka (2005), explicit knowledge is a critical type of knowledge used in the decision-making process of an organization with a centralized management type. In such an organization, tacit knowledge is a supplement to explicit knowledge. The inverse relationships take place in companies with a decentralized system of management to which virtual organizations belong. The type needed for decision-making processes of knowledge is tacit knowledge, while explicit knowledge is its supplement. 


\section{Knowledge management and company virtualization}

Virtualization of companies can be seen as transformation, through information technologies, of business activity in the conceptual, organizational, strategic and operational dimension (Mazurek, 2013). According Gembala and Palonka (2010), virtualization is a three-step process in which the elimination of time, spatial and formal barriers to doing business occurs. The first stage of virtualization is easy and fast access to information, the second level is limited and interactive communication and cooperation with users, the third relates to transaction, i.e. formal and measurable exchange of value, integrated with the information system of the company.

According to Perechuda (2013), the basic criterion of virtuality of business processes in a micro system is corporate knowledge. The more corporate knowledge is deployed in a particular product or service, the more virtual processes dominate in the enterprise (creation, transfer and utilization of knowledge). These trends are shown in Figure 3.

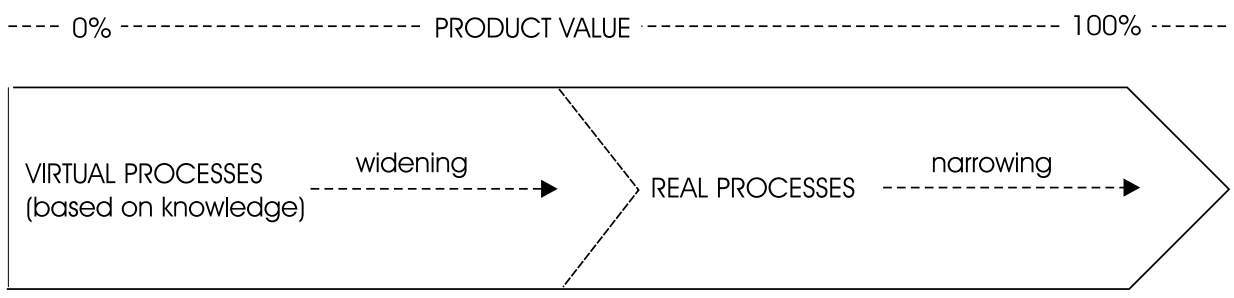

Figure 3. Trends of product virtualization.

Source: Perechuda (2013).

The value of the product is increasingly constituted by virtual processes based on knowledge. At the same time, you will notice a decreasing quantity and role of real components in enterprises. In addition, one can find the relationship between the scope of own resources of corporate knowledge and the degree of virtualization of products and services. Therefore, there appears a more and more dominant and dynamic aspect of the use of modern products and services based on knowledge (Perechuda, 2013).

Many authors indicate the relationship between technological progress and virtualization of companies. Information technologies enable the creation, transfer and use of knowledge in virtual organizations (Nonaka \& Takeuchi, 1995; Warner \& Witzel, 2005). It should be noted that although in traditional organizations the transfer of knowledge may take place in many different ways, for example, in the face-to-face contact, in virtual organizations this process cannot be implemented 
without technology. However, both knowledge and technologies cannot be effectively utilized in the organization without the participation of people.

An example of an area in business (especially virtual organizations) where the virtualization process is carried out in a comprehensive manner is marketing. In many modern organizations there takes place the transformation of the marketing communication model from one-sided into social whose axis is the interaction and exchange of information between entities. According to Mazurek (2013), in the centre of attention there is information and knowledge that the customer has in the place of information and knowledge about the customer which in the traditional model was acquired by organizations. In the opinion of Abramek (2010), companies operating in a virtual environment should, however, pay particular attention to knowledge about customers, because it helps in identifying their needs and, thus, in better adapting the offer to them, as well as enabling real-time collaboration, strategy development and a uniform image.

In virtual organizations what is particularly important is the management of relations with customers based on knowledge. Systems supporting this process are referred to as KCRM (Knowledge-Enabled Customer Relationship Management). They are a technological tool that allows not only to collect and use knowledge about customers of a company in order to obtain higher revenues but also helps managers in strategic decisions to shape the company's lasting relationships with its customers (Abramek, 2010).

Knowledge management in virtual organizations is of particular importance due to the fact that knowledge as intangible capital is more important for them than for traditional organizations. In addition, as claimed by Warner and Witzel (2005), management in virtual organizations is characterized by a lower degree of specialization. Therefore, it can be concluded that in virtual organizations the process of knowledge transformation occurs continuously and with the participation of each employee. The role of managers in virtual organizations is to activate and coordinate the process of knowledge transformation, particularly its transfer (sharing).

\section{Methods and tools of knowledge management in virtual organizations}

Knowledge management in virtual organizations is based on the use of information technologies, which determines the choice of methods and tools supporting the implementation of this process.

According to Solska (2010), elements, such as resources (tangible e.g. infrastructure and intangible e.g. knowledge), processes, methods and tools form the system architecture of knowledge management in the organization. The knowledge management system consists of the following subsystems: ${ }^{5}$

${ }^{5}$ In parentheses there are selected technologies and tools used in the realization of processes within individual subsystems. 
- search (maps of knowledge, networks),

- knowledge representation (graphs of processes, automated reasoning, hypertext),

- repository (files, database management systems),

- collaboration (forum, e-mail, process management),

- security (electronic signature, encryption),

- integration of information resources (websites, data warehouses, document management systems).

Tools to support the process of knowledge management in virtual organizations can be divided into technical and development solutions (Solska, 2010). The most important technology is the Internet, which is a network of networks, affecting the global economy and its individual elements, including a collection of resources, which can be reached via these networks and people using them, creating a virtual community. Derivative technologies include Intranet, i.e. computer network that is limited to computers and their users within one organization, and Extranet which is a network solution which involves a combination of two or more Intranets using network protocols. The purpose of Extranet is to provide information resources between organizations or between them and their customers, while limiting public access to the Internet. Other technologies and tools, in addition to the previously mentioned, include:

- CRM systems, supporting customer relationship management in the organization,

- ERP systems, integrated IT systems ensuring optimization of business processes in the enterprise,

- Business Intelligence systems, supporting the strategic decisions taken in the company,

- databases and data warehouses - analytical systems capable of storing and analysing data.

The selection of specific solutions, technologies and tools supporting knowledge management process should be carried out depending on the specifics of the enterprise, its profile, economic condition, its strategy and approach to knowledge management (Solska, 2010).

\section{Conclusions}

Knowledge, which is the most important intangible asset of virtual organizations, is generated on the basis of data and information, and as a result of an effective management process can be transformed into wisdom, understood as the ability to use 
knowledge in practice. Knowledge management is associated with the intellectual capital of organizations and determines its ability to learn and flexibly respond to changes in a turbulent environment. Virtual organizations operate within the sharing economy, in which the activities related to the transfer of information and knowledge, both within companies and between them and the stakeholders, are of particular importance. The creation, dissemination and application of knowledge using appropriate methods and technological tools should be a priority action for managers of virtual organizations wishing to achieve and maintain a competitive advantage.

Due to the fact that the process of virtualization refers to a growing number of traditional organizations and the emerging forms of doing business to a large extent bear the characteristics of virtual organizations, it is necessary to further deepen this subject in the form of theoretical considerations, supported by empirical research.

\section{References}

Abramek, E. (2010). Wpływ systemów e-biznesu na systemy zarządzania wiedzą w organizacji. In: H. Sroka, \& J. Palonka (eds.), Wplyw systemów e-biznesu na organizacje w aspekcie mikro- i makroekonomicznym (117-137). Katowice: Wydawnictwo Uniwersytetu Ekonomicznego w Katowicach.

Czekaj, J. (ed.) (2012). Podstawy zarządzania informacja, Kraków: Wydawnictwo Uniwersytetu Ekonomicznego w Krakowie.

Davoudi, S.M.M., \& Fartash, K. (2012). Knowledge management in virtual organizations. International Journal of Engineering and Management Research, 2(5), 22-28.

Dziembała, M., \& Kostrubała, S. (2010). Zmiany w wewnętrznej organizacji firm prowadzących działalność e-biznesową. In: H. Sroka, \& J. Palonka (eds.), Wplyw systemów e-biznesu na organizacje w aspekcie mikro- $i$ makroekonomicznym (117-137). Katowice: Wydawnictwo Uniwersytetu Ekonomicznego w Katowicach.

Gembala, K., \& Palonka, J. (2010). Wpływ rozwoju technologii informatycznej na kreowanie systemów e-biznesu. In: H. Sroka, \& J. Palonka (eds.), Wpływ systemów e-biznesu na organizacje w aspekcie mikro- $i$ makroekonomicznym (37-57). Katowice: Wydawnictwo Uniwersytetu Ekonomicznego w Katowicach.

Hey, J. (2004). The data, information, knowledge, wisdom chain: The metaphorical link, retrieved from: http://www.dataschemata.com/uploads/7/4/8/7/7487334/dikwchain.pdf [accessed: 29.04.2015].

Kisielnicki, J. (2008). MIS systemy informatyczne zarzadzania. Warszawa: Wydawnictwo Placet.

Kisielnicki, J., \& Sroka, H. (2005). Systemy informacyjne biznesu. Informatyka dla zarzadzania. Warszawa: Wydawnictwo Placet.

Lessing, L. (2008). Remix: making art and commerce thrive in the hybrid economy. New York: Penguin Press.

Lipińska, A. (2014). Ocena potencjału Crowdsourcingu jako elementu innowacyjnego modelu zarządzania wiedzą w przedsiębiorstwie. In: E. Skrzypek (ed.), Innowacje i ryzyko w nowej gospodarce (45-52). Lublin: UMCS. 
Mazurek, G. (2013). Wirtualizacja marketingu - konceptualizacja. In: L.W. Zacher (ed.), Wirtualizacja. Problemy, wyzwania, skutki. Warszawa: Poltext.

Nonaka, I., \& Takeuchi, H. (1995). The Knowledge-Creating Company. Oxford: The Oxford University Press.

Perechuda, K. (2013). Wirtualizacja procesów opartych na wiedzy podstawą nowoczesnego niewolnictwa. Nowe paradygmaty i determinanty przestrzeni przepływów w przedsiębiorstwie sieciowym. In: L.W. Zacher (ed.), Wirtualizacja. Problemy, wyzwania, skutki. Warszawa: Poltext.

Skrzypek, E. (2014). Zarządzanie wiedzą i jakością jako wyznaczniki sukcesu organizacji w warunkach nowej gospodarki. In: E. Skrzypek (ed.), Wplyw wiedzy na sukces organizacji $w$ nowej gospodarce (171-187). Lublin: UMCS.

Skrzypek, A., \& Senkus, P., (2014). Virtual organization in the new economy. In: A. Skrzypek (ed.), Knowledge, Innovation and Quality as Factors of the Success in the New Economy. (171-179). Lublin: UMCS.

Solska, H. (2010). Zarządzanie wiedzą. In: S. Wrycza (ed.), Informatyka ekonomiczna. Podręcznik akademicki (457-469). Warszawa: Polskie Wydawnictwo Ekonomiczne.

Sroka, H., \& Palonka, J. (2010). Problemy kreowania strategii dla organizacji w e-biznesie zamierzenia a realizacje. In: H. Sroka, \& J. Palonka (eds.), Wpływ systemów e-biznesu na organizacje $w$ aspekcie mikro- $i$ makroekonomicznym (13-36). Katowice: Wydawnictwo Uniwersytetu Ekonomicznego w Katowicach.

Tapscott, D., \& Williams, A.D. (2006). How Mass Collaboration Changes Everything. New York: Penguin Publishing Group.

Tiwana, A. (2003). Przewodnik po zarzadzaniu wiedza. E-biznes i zastosowania CRM. Warszawa: Placet.

Underwood, J. (2007). Przezwyciężanie trudności w organizacji wirtualnej. In: Biznes. Zarządzanie Firma. Vol. 2 (97-99), Warszawa: Wydawnictwo Naukowe PWN.

Vartiainen, M. (2001). The Functionality of Virtual Organizations. In: R. Suomi (ed.), The academic workshop "T -world 2001". Workshop summary, retrieved from: http://www.etw. org/2003/Archives/telework2001-proc.pdf [accessed: 30.04.2015].

Warner, M., \& Witzel, M. (2005). Zarządzanie organizacja wirtualną. Kraków: Oficyna Ekonomiczna.

\section{Note about the Author}

Aneta Lipińska - Assistant Professor in the Department of Management Systems at the Institute of Economics, Finance and Management at the Jagiellonian University. Her research interests focus on topics related to e-business, information society, the impact of information technology on management processes and organizational behaviour, information and knowledge management in the organization. 